\title{
Comparing pressures required to abolish snoring and sleep apnea
}

\author{
V Hoffstein PhD MD FRCPC, Z Oliver BSc \\ Department of Medicine, St Michael's Hospital Sleep Laboratory, \\ University of Toronto Centre for Sleep and Chronobiology, Toronto, Ontario
}

\section{Hoffstein, $\mathrm{Z}$ Oliver. Comparing pressures required to abolish snoring and sleep apnea. Can Respir J 2001;8(6):427-430.}

OBJECTIVE: Snoring and obstructive sleep apnea share similar pathogenesis and similar response to treatment with continuous positive airway pressure (CPAP). The purpose of this study was to compare pressures required to abolish apneas $\left(\mathrm{P}_{\mathrm{OSA}}\right)$ with pressures required to abolish snoring $\left(\mathrm{P}_{\mathrm{SNOR}}\right)$. DESIGN: Cross-sectional, nonrandomized cohort study. SETTING: Sleep disorders clinic at St Michael's Hospital - a tertiary referral centre and a teaching hospital of the University of Toronto, Toronto, Ontario.

POPULATION STUDIED: Unselected consecutive 441 patients with confirmed sleep apnea who were undergoing a CPAP titration study in the sleep laboratory.

INTERVENTIONS: Nocturnal polysomnography using CPAP titration protocol, which required incremental increases in pressure until snoring and apnea were abolished or a maximum pressure of $16 \mathrm{~cm} \mathrm{H}_{2} \mathrm{O}$ was attained. $\mathrm{P}_{\text {SNOR }}$ and $\mathrm{P}_{\mathrm{OSA}}$ were recorded and compared.

RESULTS: Mean ( \pm SD) pressures required to abolish snoring and apnea were: $\mathrm{P}_{\text {SNOR }} 8.3 \pm 2.57 \mathrm{~cm} \mathrm{H}_{2} \mathrm{O}$ and $\mathrm{P}_{\mathrm{OSA}}$ $7.9 \pm 2.72 \mathrm{~cm} \mathrm{H}_{2} \mathrm{O}(\mathrm{P}<0.0001)$. In $75 \%$ of patients, the $\mathrm{P}_{\text {SNOR }}$ was within $\pm 1 \mathrm{~cm} \mathrm{H} \mathrm{H}_{2} \mathrm{O}$ of the $\mathrm{P}_{\mathrm{OSA}}$; in $92 \%$, it was within $\pm 2 \mathrm{~cm} \mathrm{H}_{2} \mathrm{O}$; and in $97 \%$, it was within $\pm 3 \mathrm{~cm} \mathrm{H}_{2} \mathrm{O}$.

CONCLUSIONS: Empirically increasing pressure by $2 \mathrm{~cm}$ $\mathrm{H}_{2} \mathrm{O}$ in patients on CPAP who continue to snore may abolish snoring and apnea without the necessity of another titration study.

Key Words: Continuous positive airway pressure; Sleep apnea; Snoring

\section{Comparaison des pressions requises pour abolir le ronflement et l'apnée du sommeil}

OBJECTIF : Le ronflement et l'apnée obstructive du sommeil ont la même pathogenèse et la même réponse au traitement par ventilation spontanée en pression positive continue (VSPPC). Le but de cette étude était de comparer les pressions requises pour abolir l'apnée et le ronflement.

MODÈLE : Étude de cohorte transversale non randomisée.

CONTEXTE : Clinique des troubles du sommeil du St. Michael's Hospital, centre de soins tertiaires et centre hospitalier de l'Université de Toronto, Toronto, Ontario.

POPULATION ÉTUDIÉE : Quatre cent quarante-et-un patients consécutifs non sélectionnés présentant une apnée du sommeil confirmée et qui participaient à une étude sur l'ajustement de la VSPPC au laboratoire du sommeil.

INTERVENTION : Polysomnographie nocturne à l'aide d'un protocole d'ajustement de la VSPPC qui nécessitait des augmentations graduelles de pression jusqu'à ce que le ronflement et l'apnée soient abolis ou jusqu'à l'atteinte d'une pression maximum de $16 \mathrm{~cm}$ de $\mathrm{H}_{2} \mathrm{O}$. Les deux types de pression ont été notés et comparés.

RÉSULTATS : Les pressions moyennes ( \pm écart-type) nécessaires pour abolir le ronflement et l'apnée ont été respectivement de $8,3 \pm 2,57 \mathrm{~cm} \mathrm{H}_{2} \mathrm{O}$ et $7,9 \pm 2,72 \mathrm{~cm} \mathrm{H}_{2} \mathrm{O}(\mathrm{p}<0,0001)$. Chez $75 \%$ des patients, la pression requise pour cesser le ronflement était à $\pm 1 \mathrm{~cm} \mathrm{H}_{2} \mathrm{O}$ de la pression nécessaire pour mettre fin à l'apnée. Chez $92 \%$, la différence se situait à $\pm 2 \mathrm{~cm} \mathrm{H}_{2} \mathrm{O}$ et chez $97 \%$, à $\pm 3 \mathrm{~cm} \mathrm{H}_{2} 0$.

CONCLUSION : En augmentant empiriquement la pression de $2 \mathrm{~cm} \mathrm{H}_{2} \mathrm{O}$ chez les patients sous VSPPC, qui ronflent toujours, on peut abolir le ronflement et l'apnée, sans nécessairement procéder à une autre étude d'ajustement. 
Cnoring is the most common symptom of obstructive sleep apnea (OSA). It heralds the onset of inspiratory flow limitation, generally preceding hypopneas and apneas. Consequently, it seems intuitively correct that during application of continuous positive airway pressure (CPAP), snoring is abolished before apneas and hypopneas. This is why, in some laboratories during CPAP titration studies, a sleep technologist frequently increases the pressure if snoring is present. Even some self-titrating CPAP systems are programmed to adjust the pressure depending on the presence or absence of snoring. Finally, given the financial and logistical constraints inherent in repeating nocturnal polysomnography, many physicians caring for patients with sleep apnea assume that persistent snoring is a sign of continuing apneic activity and recommend increasing the pressure. However, there are no previous studies investigating the relationship between pressures required to abolish snoring $\left(\mathrm{P}_{\mathrm{SNOR}}\right)$ and pressures required to abolish sleep apnea $\left(\mathrm{P}_{\mathrm{OSA}}\right)$. Consequently, the objective of our study was to compare these pressures in patients with sleep apnea undergoing CPAP titration.

\section{PATIENTS AND METHODS}

Four hundred forty-one consecutive, unselected patients with confirmed OSA undergoing an in-laboratory CPAP titration study were included in the present study. None of the patients had received previous treatments for sleep apnea (surgery, oral appliances, etc).

The monitoring included electroencephalograms, submental and anterior tibial electromyograms, oxygen saturation, cardiac rhythm, movements of the chest wall and abdomen using Respitrace (Ambulatory Monitoring Inc, USA), and oronasal flow using thermocouple with oral and nasal thermistors.

The starting pressure $\left(\mathrm{P}_{\text {start }}\right)$ for CPAP titration was calculated for each patient using a prediction formula derived from the authors' previous work (1), as follows:

$$
P_{\text {start }}=0.16 \times \mathrm{BMI}+0.13 \times \mathrm{NC}+0.04 \times \mathrm{AHI}-5.12
$$

$\mathrm{BMI}$ is the body mass index (weight $[\mathrm{kg}] /$ height $\left[\mathrm{m}^{2}\right]$ ), $\mathrm{NC}$ is the neck circumference measured in $\mathrm{cm}$, and AHI (the apnea/hypopnea index) is the sum of apneas and hypopneas $/ \mathrm{h}$ of sleep, determined during diagnostic polysomnography. The pressure was increased (or decreased) in increments of $1 \mathrm{~cm} \mathrm{H}_{2} \mathrm{O}$ depending on whether the AHI was higher (or low-

\section{TABLE 1} Anthropometric data and diagnostic apnea/hypopnea
index in 441 patients

\begin{tabular}{lcc}
\hline Variable & Mean \pm SD & Range \\
\hline Age (years) & $51 \pm 11.4$ & $17-81$ \\
Weight $(\mathrm{kg})$ & $98.7 \pm 23.27$ & $53-220$ \\
Body mass index $\left(\mathrm{kg} / \mathrm{m}^{2}\right)$ & $33.6 \pm 7.38$ & $19.7-68.9$ \\
Neck circumference $(\mathrm{cm})$ & $42.7 \pm 4.37$ & $30-59$ \\
Apnea/hypopnea index & $47 \pm 27.2$ & $10-134$ \\
\hline
\end{tabular}

er) than 10. Once the pressure at which AHI became lower than 10 was achieved $\left(\mathrm{P}_{\mathrm{OSA}}\right)$, further increments in pressure were dictated by technologist's perception of snoring. The study was terminated when snoring was abolished $\left(\mathrm{P}_{\mathrm{SNOR}}\right.$ was recorded), when the lowest pressure of $2 \mathrm{~cm} \mathrm{H}_{2} \mathrm{O}$ was reached or when the highest pressure of $16 \mathrm{~cm} \mathrm{H}_{2} \mathrm{O}$ was reached. The authors did not go to higher pressures because in their clinical experience, they are generally poorly tolerated by patients, and the authors consider using bilevel positive airway pressure rather than CPAP. The common clinical definition of sleep apnea was used, based on an AHI greater than 10. There is some evidence, particularly in patients with upper airway resistance syndrome, that "sleep apnea symptoms" (2) may persist, even if the conventional AHI is below 10. On the other hand, recent studies by Hosselet et al (3) suggest that snorers with excessive daytime sleepiness have a total respiratory disturbance index greater than 18 . In view of the considerable variability in the laboratory definition of sleep apnea, we decided to use an AHI less than 10 as the end point of CPAP titration.

Paired $t$ test, correlation analysis and examination of frequency distribution were used to examine the relationship between $\mathrm{P}_{\mathrm{SNOR}}$ and $\mathrm{P}_{\mathrm{OSA}}$.

\section{RESULTS}

Anthropometric data and the AHIs obtained during the diagnostic polysomnography are given in Table 1 for all 441 patients (370 men and 71 women). The study group was very heterogeneous with respect to age, obesity and the severity of sleep apnea.

Of the 441 patients, 129 did not snore at all during the titration study (despite lowering the pressure to $3 \mathrm{~cm} \mathrm{H}_{2} \mathrm{O}$ ), and eight patients snored at all pressures up to $16 \mathrm{~cm} \mathrm{H}_{2} \mathrm{O}$; in the remaining 304 patients, snoring and apneas were successfully eliminated during CPAP titration. The characteristics of these three groups of patients (no snoring during titration, continuous snoring during titration and snoring abolished during titration) are shown in Table 2. Only age and the final AHI were significantly different between the groups.

\section{TABLE 2}

\section{Patients grouped by adequacy of snoring disappearance during continuous positive airway pressure titration}

\begin{tabular}{lccc}
\hline Variable & $\begin{array}{c}\text { No snoring } \\
(\mathbf{n}=\mathbf{1 2 9})\end{array}$ & $\begin{array}{c}\text { Continuous } \\
\text { snoring } \\
(\mathbf{n}=\mathbf{8})\end{array}$ & $\begin{array}{c}\text { Snoring } \\
\text { abolished } \\
(\mathbf{n}=\mathbf{3 0 4})\end{array}$ \\
\hline $\begin{array}{l}\text { Age (years) } \\
\text { Body mass } \\
\quad \text { index }\left(\mathrm{kg} / \mathrm{m}^{2}\right)\end{array}$ & $54 \pm 11.8$ & $47 \pm 16.1$ & $49 \pm 10.9$ \\
$\begin{array}{l}\text { Neck circumference }(\mathrm{cm}) \\
\text { Diagnostic apnea/ }\end{array}$ & $42.3 \pm 4.04$ & $42.2 \pm 6.49$ & $42.7 \pm 4.33$ \\
$\quad$ hypopnea index & $43.4 \pm 25.37$ & $34.2 \pm 18.29$ & $46.8 \pm 27.71$ \\
$\begin{array}{l}\text { Final apnea/ } \\
\quad \text { hypopnea index }\end{array}$ & $7.3 \pm 7.93$ & $12.0 \pm 17.42$ & $5.3 \pm 4.18$ \\
$\mathrm{P}_{\text {OSA }}$ & $7.3 \pm 2.33$ & $8.8 \pm 3.52$ & $7.9 \pm 2.72$ \\
\hline$P_{\text {OSA }}$ Pressure required to abolish sleep apneas & \\
\hline
\end{tabular}


The $\mathrm{P}_{\mathrm{SNOR}}$ was clinically similar to, although statistically significantly higher than, the $\mathrm{P}_{\mathrm{OSA}}$ in 304 patients $\left(\mathrm{P}_{\mathrm{SNOR}}\right.$ $8.3 \pm 2.57 \quad \mathrm{~cm} \mathrm{H}_{2} \mathrm{O}$ versus $\mathrm{P}_{\mathrm{OSA}} 7.9 \pm 2.72 \mathrm{~cm} \mathrm{H}_{2} \mathrm{O}$, $\mathrm{P}<0.0001) . \mathrm{P}_{\mathrm{SNOR}}$ and $\mathrm{P}_{\mathrm{OSA}}$ were significantly correlated: $\mathrm{r}=0.86, \mathrm{P}=0.0001$.

The distribution of the differences between the $\mathrm{P}_{\mathrm{SNOR}}$ and the $\mathrm{P}_{\mathrm{OSA}}$ is shown in Figure 1. We note that in 227 of 304 patients (75\%), the $\mathrm{P}_{\mathrm{SNOR}}$ was within $\pm 1 \mathrm{~cm} \mathrm{H}_{2} \mathrm{O}$ of the $\mathrm{P}_{\mathrm{OSA}}$; in 279 of 304 patients (92\%), they were within $\pm 2 \mathrm{~cm} \mathrm{H}_{2} \mathrm{O}$; and in 295 of 304 patients (97\%), they were within $\pm 3 \mathrm{~cm} \mathrm{H}_{2} \mathrm{O}$. In 137 of 304 patients (45\%), the $\mathrm{P}_{\mathrm{SNOR}}$ was higher than the $\mathrm{P}_{\mathrm{OSA}}$, and in an additional 102 of 304 patients (34\%), both pressures were equal. In the remaining 65 of 304 patients $(21 \%)$, the $\mathrm{P}_{\mathrm{SNOR}}$ was lower than the $\mathrm{P}_{\mathrm{OSA}}$; in other words, $21 \%$ of patients whose snoring was abolished still had sleep apnea at that pressure.

\section{DISCUSSION}

Our results indicate that in unselected patients with sleep apnea who had never had any surgical manipulation of the upper airway, snoring is not a good surrogate measure of apneic activity. First, $31 \%$ of patients either did not snore at all or snored continuously during CPAP titration. Second, the 'false-negative' rate of snoring abolition as a marker of apnea abolition was, at best, $21 \%$ and perhaps as high as $44 \%$ if we assume that all 129 patients who did not snore at all during CPAP titration continued to have sleep apnea. However, in $69 \%$ of patients, the $\mathrm{P}_{\mathrm{SNOR}}$ was almost identical to the $\mathrm{P}_{\mathrm{OSA}}$; in over $90 \%$ of these patients, the two pressures were within $\pm 2 \mathrm{~cm} \mathrm{H}_{2} \mathrm{O}$. Because apneas and hypopneas are generally preceded by snoring, one may intuitively expect that the $\mathrm{P}_{\mathrm{SNOR}}$ is lower than the pressure that abolishes other respiratory events. However, this is not always the case. For example, Berry and Block (4), investigating the effect of CPAP on snoring and apneas, noticed that "higher pressure was needed to abolish snoring than to stop sleep-disordered breathing and improve oxygenation." Theoretical and experimental studies of airway dynamics during sleep (5) indicate that snoring appears after flow limitation is reached, when an airway segment becomes unstable, and airway walls begin to vibrate. Ayappa et al (6) pointed out that flow limitation and snoring are good signs of impending apneas and hypopneas. In fact, flow limitation may be an even earlier indicator of airway obstruction than snoring, but it requires more sophisticated technology for detection than snoring. Similarly, Berkani et al (7), who studied 10 patients with sleep apnea during CPAP titration using an auto-CPAP device, found that in $80 \%$ of patients, the $\mathrm{P}_{\mathrm{SNOR}}$ also abolished sleep apnea, while the remaining $20 \%$ required a pressure $2 \mathrm{~cm} \mathrm{H}_{2} \mathrm{O}$ higher. The authors concluded that patients with diagnosed sleep apnea may be started on home CPAP without a formal titration study using an auto-titrating device based on snoring detection.

Can the results of the present study therefore be used to advise patients with sleep apnea treated with CPAP at home to empirically increase the pressure by $2 \mathrm{~cm} \mathrm{H}_{2} \mathrm{O}$ if they still

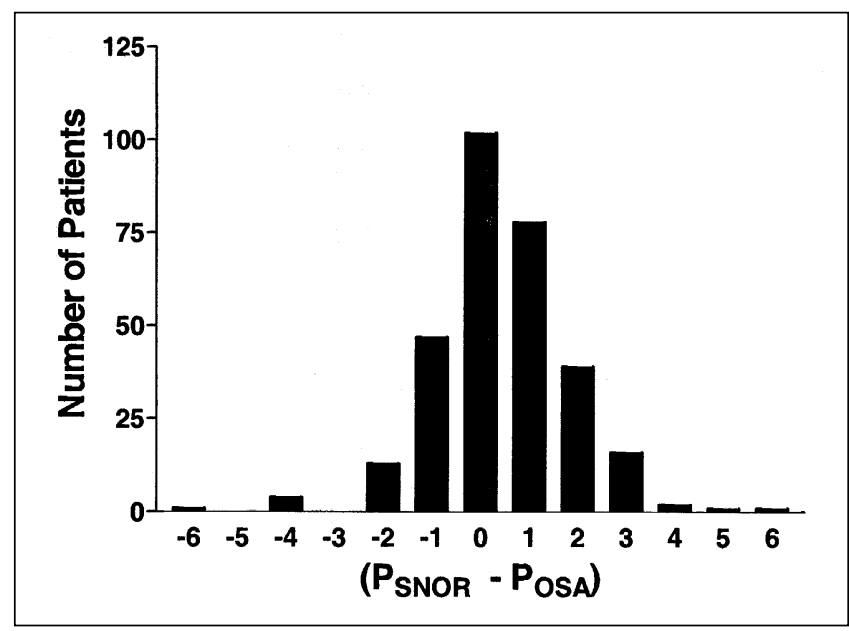

Figure 1) Histogram of the differences between pressures required to abolish snoring and sleep apnea. $P_{O S A}$ Pressure required to abolish sleep apneas; $P_{S N O R}$ Pressure required to abolish snoring

snore? To answer this question, we must first discuss some of the limitations inherent in the type of clinical study we conducted.

Lack of an objective measurement of snoring: An objective measurement of snoring was purposely not used for two reasons. First, our system of measuring snoring employed a microphone attached to the nasion, and CPAP introduced a variable background noise that may have interfered with measurements of snoring sound. Second, we wanted to extrapolate our results to the home situation and, therefore, wished to examine the usefulness of subjective perception (presumably by the bedpartner) of continuing snoring as a marker of persistent sleep apnea in patients on CPAP. We are well aware that subjective perception of snoring is probably different between the bed partner and the sleep technologist. Two people listening to the same snorer disagree whether the sound is snoring up to $30 \%$ of the time (8). It is possible that an experienced technologist who is used to hearing frequent and loud snoring sounds in the sleep laboratory may have a tendency to underestimate the severity of snoring. This, in fact, may be the reason why so many of our patients 'did not snore' during the study.

Lack of in-home monitoring: Can we apply our results to patients on CPAP at home who still snore? Does our result (the difference between the $\mathrm{P}_{\mathrm{SNOR}}$ and the $\mathrm{P}_{\mathrm{OSA}}$ being within $\pm 2 \mathrm{~cm} \mathrm{H}_{2} \mathrm{O}$ in over $90 \%$ of patients) obtained during inlaboratory CPAP titration hold for sleep at home? We do not have data to answer this question. However, based on previous investigations (9), we expect that snoring and apneas objectively measured at home are not very much different from those measured in the laboratory using the same objective means.

Effect of body position: Absence of careful monitoring of body position may potentially influence our results. It is theoretically possible that the differences in the $\mathrm{P}_{\mathrm{SNOR}}$ and the $\mathrm{P}_{\mathrm{OSA}}$ reflect the differences in body position, eg, apneas were 
abolished when patients were lying on their side, while snoring was abolished when patients were on their back. This scenario is unlikely. Our clinical observation is that during CPAP titration, patients are most frequently lying on their back.

Notwithstanding the above limitations, we submit that it is still reasonable to use our findings for making clinical decisions in patients with sleep apnea treated with CPAP.

If a patient snores while on CPAP, there is a $21 \%$ chance of apnea persisting and a $79 \%$ chance that apnea is abolished, but higher pressures may be needed to abolish snoring. Increasing the pressure by $2 \mathrm{~cm} \mathrm{H}_{2} \mathrm{O}$ (rather than $3 \mathrm{~cm} \mathrm{H}_{2} \mathrm{O}$, which may be more difficult to tolerate) should abolish apneas and snoring, without repeating nocturnal polysomnography. If snoring still persists (in the absence of obvious new clinical risk factors such as increased weight, ingestion of alcohol, nasal obstruction, etc), the patient should be restudied again while on CPAP.

On the other hand, the absence of snoring while on CPAP provides less useful clinical information - it cannot be used as an indicator that apnea is abolished, because $29 \%$ of patients did not snore at all during titration, despite persistent apneas. Consequently, if a nonsnoring patient on CPAP continues to have sleep apnea symptoms, there are several possibilities to consider. First, there may be persistent apnea, because the pressure may be inadequate for a home situation, equipment may be used incorrectly or leaks around the mask may occur, etc. Second, there may be another sleep-related problem such as periodic leg movements. Lastly, patients' symptoms may be unrelated to sleep. We do not have the data to recommend an appropriate course of action in this situation. We speculate that the best diagnostic yield is achieved if nocturnal polysomnography is repeated on CPAP rather than treating empirically possible persistent apnea.

\section{CONCLUSIONS}

The present study found that pressures that eliminate snoring and apneas are similar in the majority of patients and are within $\pm 3 \mathrm{~cm} \mathrm{H}_{2} \mathrm{O}$ in virtually all of them. This provides a justification for empirical (ie, without repeat nocturnal polysomnography) adjustments of pressure in patients on CPAP who continue to snore with or without persistent symptoms of sleep apnea.

\section{REFERENCES}

1. Oliver Z, Hoffstein V. Predicting effective continuous positive airway pressure. Chest 2000;117:1061-4.

2. Guilleminault C, Stoohs R, Clerk A, Cetel M, Maistros P. A cause of excessive daytime sleepiness: the upper airway resistance syndrome. Chest 1993;104:781-7.

3. Hosselet JJ, Ayappa I, Norman RG, Krieger AC, Rapoport DM. Classification of sleep-disordered breathing. Am J Respir Crit Care Med 2001;163:398-405.

4. Berry RB, Block AJ. Positive nasal airway pressure eliminates snoring as well as obstructive sleep apnea. Chest 1984;85:15-20.

5. Dalmasso F, Prota R. Snoring: analysis, measurement, clinical implications, and applications. Eur Respir J 1996;9:146-59.

6. Ayappa I, Norman RG, Hosselet JJ, et al. Relative occurrence of flow limitation and snoring during continuous positive airway pressure titration. Chest 1998;114:685-90.

7. Berkani M, Lofaso F, Chouaid C, et al. CPAP titration by an auto-CPAP device based on snoring detection: a clinical trial and economic considerations. Eur Respir J 1998;12:759-63.

8. Hoffstein V, Mateika S, Nash S. Comparing perception and measurements of snoring. Sleep 1996;19:783-9.

9. Sériès F, Marc I, Atton L. Comparison of snoring measured at home and during polysomnographic studies. Chest 1993;103:1769-73. 


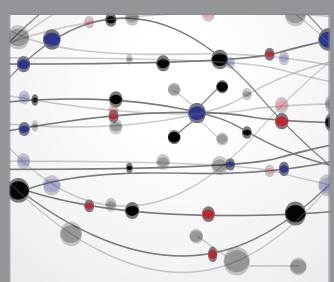

The Scientific World Journal
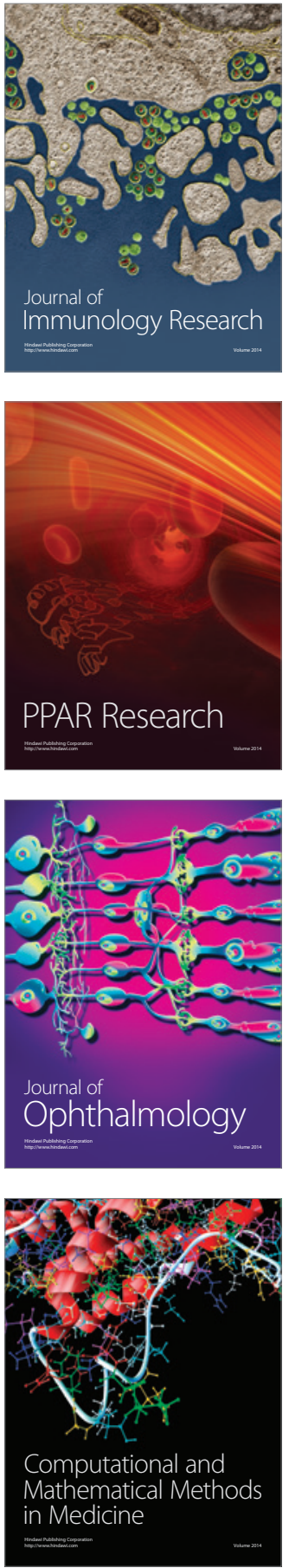

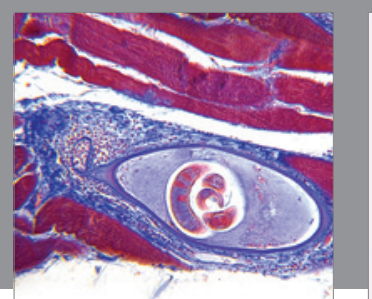

Gastroenterology Research and Practice

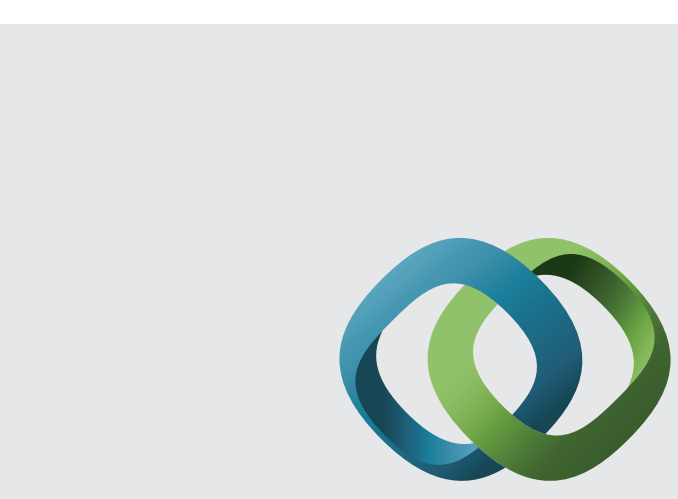

\section{Hindawi}

Submit your manuscripts at

http://www.hindawi.com
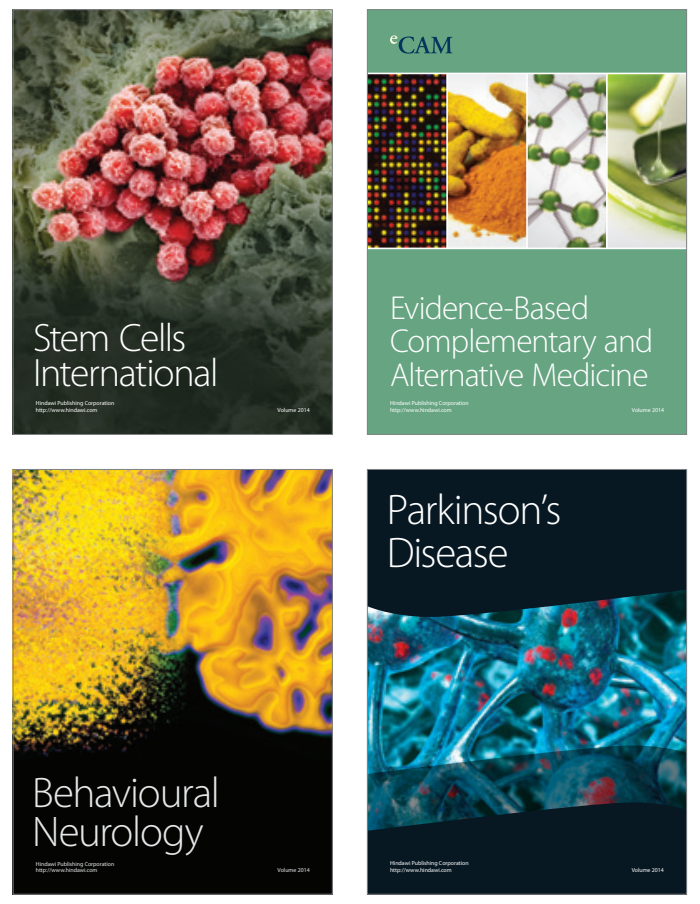
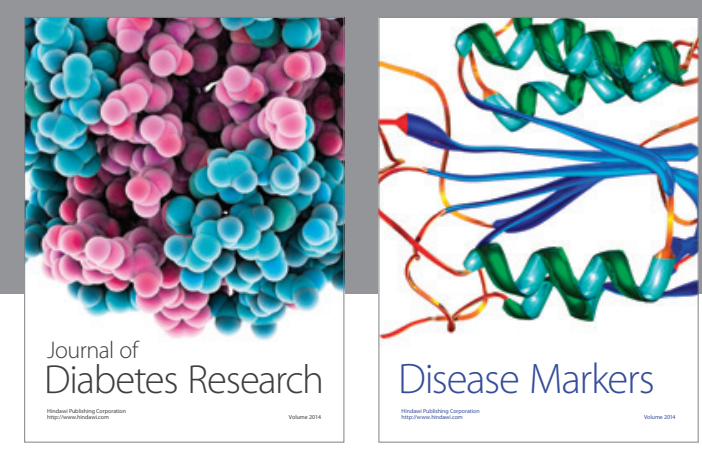

Disease Markers
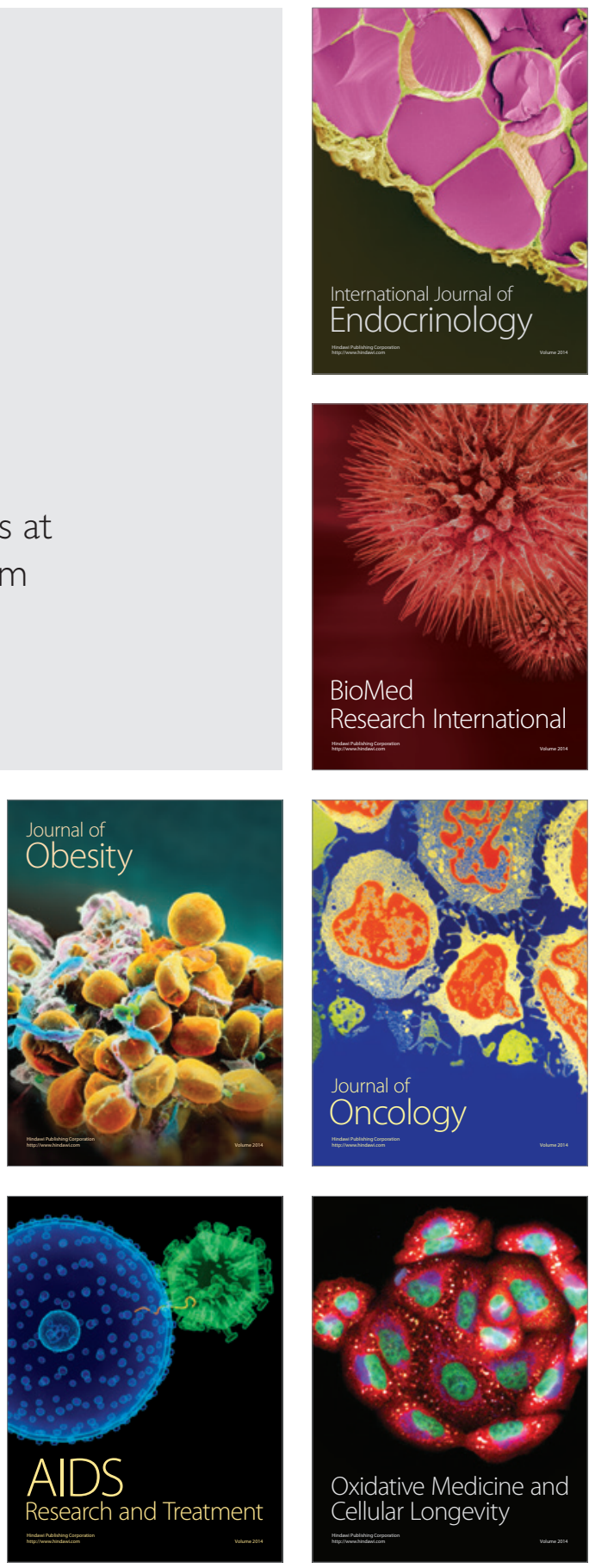